\begin{tabular}{c} 
Volume and Issues Obtainable at Center for Sustainability Research and Consultancy \\
Journal of Business and Social Review in Emerging Economies \\
ISSN: 2519-089X (E): 2519-0326 \\
Volume 3: Issue 2December 2017 \\
CSRᄃ \\
Journal homepage: $\underline{\text { www.publishing.globalcsrc.org/jbsee }}$ \\
\hline
\end{tabular}

\title{
Impact of Transformational Leadership and the Mediating Effect of Employees' Perception of Organizational Change on Affective, Normative and Continuance Commitment
}

\author{
${ }^{1}$ Joshua Teck Khun Loo, ${ }^{2}$ Pey Huey Lee, ${ }^{3}$ Ai Loon Low \\ ${ }^{1}$ DISTED College Penang, 340, Jalan Macalister, 10450 George Town, Penang, \\ Malaysia.captjoshualoo@yahoo.com \\ 2 TAR University College, 77, LorongLembahPermai 3, 11200 TnjungBungah, Penang, Malaysia. \\ jocelyn_phlee@yahoo.com.au \\ ${ }^{3}$ SEGi College Penamg, 10200 George Town, Penang, Malaysia, \\ ailoon_low@yahoo.com
}

\section{ARTICLEDETAILS}

History

Revised format: Nov 2017

AvailableOnline: Dec 2017

\section{Keywords}

Employees' Perception of

Organizational Change,

Affective Commitment,

Normative Commitment,

Continuance Commitment,

Transformational Leadership

JEL Classification:

D23, D29

\begin{abstract}
Purpose:The purpose of this research paper is to study the influence of transformational leadership on employees' perception of the change and the impact of the different levels of commitment towards change in a semi-conductor multinational company in Malaysia.

Design/Methodology/Approach:The partial least squares of structural equation modelling (PLS-SEM) approach was deployed to validate and examine the research theoretical framework, and conduct the hypothesis testing.

Findings:The result reveals transformational leadership and employees' perception of the changes to be highly predictive of the employees' commitment with regard to the organizational changes. It also indicates that employees' perception of the change has a significant mediating effect on the relationship between transformational leadership and affective, normative, and continuance commitment.

Implications/Originality/Value:Management must be sensitive to employees' reaction for the change initiatives to be successful and it is noteworthy for management to understand the employees' perception of the changes, support their needs to cope with the changes in their effort to overcome these resistances.
\end{abstract}

(C) 2017 The authors, under a Creative Commons AttributionNonCommercial-ShareAlike 4.0

Corresponding author's email address: captjoshualoo@yahoo.com

Recommended citation:Loo,J.T.K., Lee,P.H. \&Low,A.L., (2017).Impact of Transformational Leadership and the Mediating Effect of Employees' Perception of Organizational Change on Affective, Normative and Continuance Commitment.Journal of Business and Social Review in Emerging Economies, 3(2) 185-198.

DOI:https://doi.org/10.26710/jbsee.v3i2.99

\section{Introduction}

In the vigorous business world today, change is vital and organization requires more than just incremental adjustment to their strategy but a constant reinvention in order to survive (Cossin\& Caballero, 2013). Nearly $70 \%$ of all change initiatives failed due to lack of consideration placed on the human factor such as employees' resistance to change (Beer \&Nohria, 2000; Martin, Jones \& Callan, 2006; Ford, Ford \&D'Amelio, 2008). Resistance is natural in the change process as change moves status quo, creates 
uncertainty, anxiety and tension that affect a person's perception of the change situation. This perception will subsequently determine whether resistance occurs (Connor, 1993) and employees' attitude, psychological and behavioral elements during organization change are essential in the success of the change initiatives (Bernerth, 2004).

As a result, change leader's role in creating a sense of continuity for their employees in the midst of a changing environment is important (Boselie\&Koene, 2010; Lamm\& Gordon, 2010; Van Dijk\& Van Dick, 2009). A leader's behavior and approaches in handling employees' emotions, and perceptions can positively influence their commitment towards organizational changes (Bass \&Riggio, 2006; Groves, 2005).

This study is conducted on XYZ Limited, a semiconductor multinational company in Malaysia, focusing on telecommunication devices and infrastructure. Due to the rapid shift in the technology landscape of this industry, XYZ Limited needs to transform itself to match the current market dynamics such as lower margins, commoditization, new technologies and competition from outside the traditional market. Major organizational changes are required to increase customers' satisfaction, to enhance revenue streams and cost savings are inevitable. Although the changes are important for survival of the company, the employees are behaving unfavorably towards the changes. This is evidenced by a drop in employees' satisfaction index from $85 \%$ in 2014 to $71 \%$ in 2015 as shown in the employee's satisfaction survey of the company.

The present study aims to provide insights to XYZ Limited in overcoming the challenges in managing the organizational changes. Given the internal and external pressures to initiate the change, XYZ Limited has little choice but to look into the human factor to gain commitment of its employees to support the change implementation and improve the organizational performance (Kotter \& Cohen, 2002). Therefore, the relationship between transformational leadership, employees' perception of organizational change, and organizational commitment in the context of XYZ Limited is examined. The objective of this research is to study the impact of transformational leadership and the mediating effect of employees' perception of organizational change on employees' affective, normative and continuance commitment.

\section{Literature Review}

\subsection{Theories of Change}

Organizational change includes changes of individual, job or company structure that impacts on what people do, how they perform their tasks, their responsibilities and accountabilities. Previous studies have shown that effective organizational changes are able to revive troubled companies through corporate turnaround (Hofer,1980; Bibeault, 1982; Hambrick\&Schecter, 1983; Barker \&Duhaime, 1997).

The actual value added from organizational change is its capability to change the organization's strategy, identity, operation, structure or human resources as sources to improve the companies' performance (Vithessonthi, 2007).

\subsection{Employees' Perception}

Bem (1972) explains that perceptions hold an important role in forming employees' behaviors and response to the change. Although changes proposed are to benefit the organization as a whole, it takes time for the benefits to be realized. When employees are unable to see the potential benefits in the short run, they may resist the intended change (Hannan\& Freeman, 1988). When employees are highly skeptical of the change initiatives, their productivity and morale will decrease and attrition rate will increase. This will subsequently fail the change effort (Greiner, 1992; Dervitsiotis, 1998; Goldstein, 1998; Eby, Freeman, Rush \& Lance, 1999). Hence, recognizing the importance of achieving positive employee attitudes is crucial in successful organizational change (Ebyet al., 1999; Martin, 1998).

As Lord and Emrich (2001) suggested, it is vital for the leaders to discover what the followers are 
thinking as organizational change can only happen when majority of individuals change their attitudes or behaviors (Alas \&Vadi, 2006). Meyer and Allen (1997) also stated that perception is more important than reality, and employee's perception of the change initiative should concur with the organization's vision to enable them to devote to the changes (Noble \&Mokwa, 1999). Thus, it is important to understand the factors affecting employees' perception of the organizational change as these perceptions would contribute to their behavioral support (Lamm\& Gordon, 2010) and regulate their reactions towards the change.

\subsection{Organizational Commitment}

According to the Three Component Model (TCM) of Herscovitch and Meyer (2002), affective commitment (AC), continuance commitment (CC) and normative commitment (NC) are the three dimensions of commitment to change. The degree of behavioral support for change will largely depends on the combination, and level of these commitments.

$\mathrm{AC}$ refers to the degree of devotion an individual has for the organization. It is the employees' emotional bond and desire to commit to the organization (Porter, Steers, Mowday\&Boulian, 1974). Meyer and Allen (1997) asserted that employees with high AC exhibit identification and emotional attachment through their participation in the organization. This is the highest level of commitment that is most sought after by the organization.

CC stands for the perceived costs of separation from the organization. Thus, continuance commitment is also known as calculative commitment (Hackett \&Bycio, 1994). Becker (1960) defined CC as a process where employees are "locked" into the organization due to the cost liable upon leaving, such as seniority, pension fund and so on.

$\mathrm{NC}$ is represented by employees' perceived obligation to stay engaged to the organization. This is caused by the urge to reciprocate organizational investments and an effect of socialization into cultural norms in terms of loyalty to the organization (Meyer \& Allen, 1991; Meyer \& Allen, 1997; Meyer, Gagné,\&Parfyonova, 2010). NC focuses on moral responsibilities such as "right thing to do", and concentrating on the obligation of the employees to the organizational goals (Weiner, 1982; Allen \& Meyer, 1990).

Previous studies have shown that $\mathrm{AC}$ and $\mathrm{NC}$ are positively related to the level of perceived transformational leadership, organizational support and various types of organizational justice whereas, the relationships between perceived organizational support with $\mathrm{CC}$ is minimal (Machin, Fogarty, \& Bannon, 2009). Therefore, while CC is enough to encourage conformity with change, AC and NC are needed for higher level of support (Herscovitch\& Meyer, 2002).

\subsection{Leadership}

There are numerous studies examining different types of leadership. However, contemporary literature mainly centers on the two main aspects of leadership, which are transactional and transformational leadership founded by Burns (1978).

According to Burns (1978), transactional leadership focuses on leader-follower exchanges. Leaders will positively reward followers who perform according to their commands and directions and punish followers who fail to comply with them. Transformational leaders on the other hand, are able to change the attitude and beliefs of followers, and motivate the subordinates in their own interests to concur with the advancement of the organization.

In times of change, two of the most influential factors affecting the amount of confidence employees have in their leaders are the employees' ability to identify with their leader, and the degree to which employees 
perceive their leaders as competent (Boselie\&Koene, 2010). In this context, transformational leadership is presently regarded as the most effective type of leadership for organizational changes (Yukl, 2002) because it connects leadership to job performance through leader-member and co-worker relationships (Li \& Hung, 2009). Therefore, transformational leadership is the type of leadership being chosen to be studied in this research.

\subsection{Transformational Leadership}

During organizational changes, transformational leadership was found to be the most effective leadership style as it is able to enhance employees' commitment to change through its four elements, which are idealized influence, inspirational motivation, intellectual stimulation and individualized consideration (Bass, Avolio, Jung \&Berson, 2003).

Idealized influence is what makes others feel proud to be related with the leader therefore earning the faith of the subordinate (Bass, 1990). Transformational leaders act as a role model to the employees by displaying high ethical behavior to gain their respect and trust. When the employees feel proud to be associated to the leader, they will cooperate and be committed to change (Chan \&Mak, 2014).

Inspirational motivation is the effectiveness of the leader in communicating his goals or a vision that is inspiring to the followers, manipulating the images of future goals in an optimistic manner, and helping others find meaning in their work. Individual and team spirit is aroused, enthusiasm and optimism are displayed (Bass et al., 2003). When a transformational leader is able to communicate the organizational change requirements precisely, the employees' perception of the change initiative tend to align with the organization's vision which motivates them to commit to the change (Parish, Cadwallader\& Busch, 2008).

Intellectual stimulation takes place when the leaders encourage employees to challenge the assumptions, take risks, be creative and implement innovations that translate into good relationships in the workplace (Korkmaz, 2007). Learning is valued and employees are encouraged to ask questions, and figure out more effective ways to perform their tasks. Employees will perceive this as sharing of control which will foster greater commitment to organizational change (Dodd \&Ganster, 1996). As a result, when the employees trust, admire and respect the leader due to the qualities of the transformational leadership, they are willing perform beyond expectation (Gillespie \& Mann, 2004; Podsakoff, MacKenzie\&Bommer, 1996).

The last element of transformational leadership is individualized consideration. Leaders with such behavior care about the needs of the individual followers, acts as a coach or mentor, and provides support to increase the employees' success in the change. (Bass et al., 2003) Studies indicated that this kind of perceived organizational support is a crucial psychological resource for employees as it will increase their commitment to the organization (Eisenberger, Huntington, Hutchison \& Sowa, 1986). Researchers showed that employees who perceived that their managers are supportive have the tendency to be more devoted to the organizational changes (Johnson, Parasuraman, Futrell \& Black, 1990).

Research results supported the statement made by Bass and Avolio (1990) which is, transformational leaders' charisma are able to transform, motivate and intellectually stimulate the employees to attain new and distinctive ways to challenge the status quo and change the environment to support successful changes. Other research indicated that the association between transformational leadership and affective organizational commitment is positively strong (Avolio, Zhu, Koh\& Bhatia, 2004; Spreitzer, Perttula\& Xin, 2005) and is able to increase group effectiveness by enhancing group motivation, efficiency and performance (Cohen, Chang \& Ledford, 1997; Walumbwa, Wang, Lawler \& Shi, 2004). Transformational leadership style shows positive impact on employees' perception and commitment (Tseng \& Kang, 2008; Mert, Keskin\& Bas, 2010).

\section{Underlying Theory}


The research framework mainly explores the attribution theory (Miles, 2012) to examine the mediating effect of employees' perception of organizational change in the relationship between transformational leadership and employees' commitment (AC, NC and CC). According to Weick (1999), behavioral consequence is one of the most prominent phases of attribution process and it has been proven that people tend to perceive and react based on external and internal factors (DiVitto \& McArthur, 1978). Besides, this theory also has been applied to understand the influence of leadership style on the external factor of behavioral consequence (Ellis, Ilgen \& Hollenbeck, 2006). Hence, this study deployed transformational leadership as an exogenous of employees' perception of organizational change. On the other hand, employees' perception of organizational change was deployed as exogenous of AC, NC and CC.

\section{Conceptual Research Framework and Hypotheses Development}

This research investigates the effectiveness of leadership competencies on influencing the employees' perception of the organizational change towards employees' commitment in a multinational company in Malaysia. Although previous studies have investigated the relationship between transformational leadership and employees' perception of the organizational change as well as the relationship between employees' perception of the organizational change and employees' commitment, very little attention was given on the mediating effect of the employees' perception of organizational change in the relationship between the effectiveness of leadership and employees' commitment. Thus, Figure 1 illustrates the connection between transformational leadership (independent variable), employees' perception of the organizational change (mediating variable), affective, normative and continuance commitment (dependent variables).

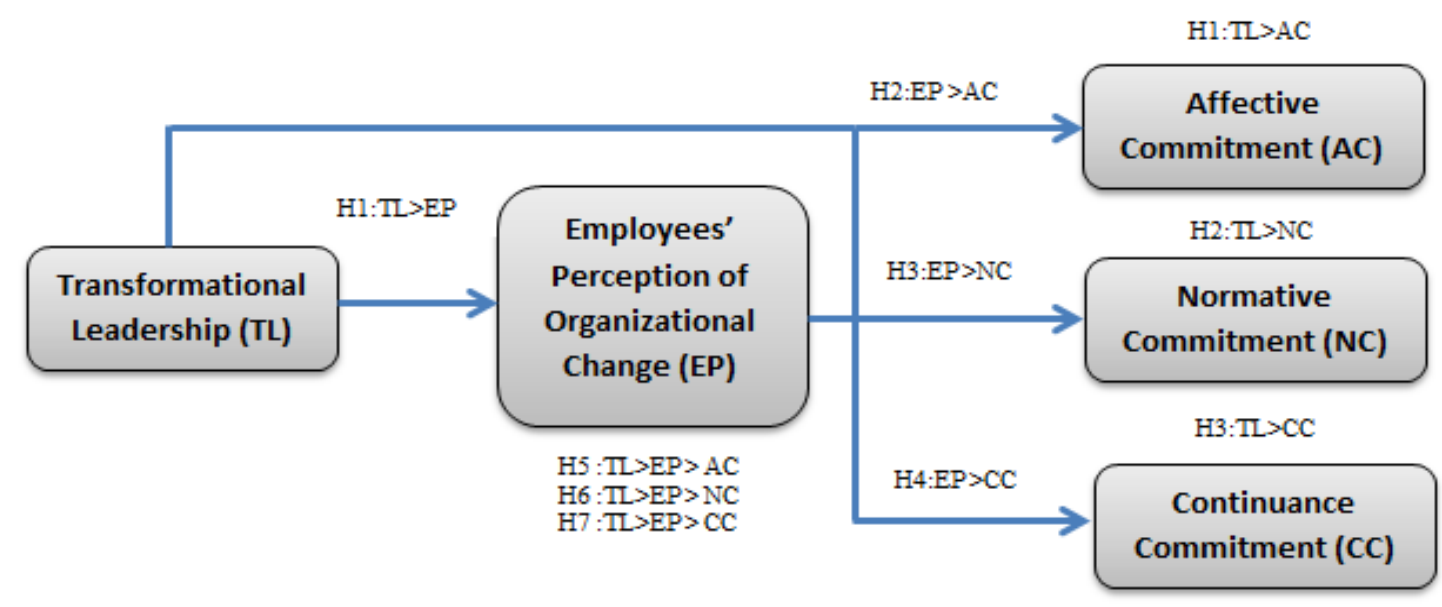

Figure 1: Theoretical Research Framework

In this study, the conceptual framework indicates one direct effect between independent variable and mediating variable, mediating variable and dependent variables, and indirect effect between independent variable, mediating variable and dependent variables. Hence the theoretical research framework consists of seven hypotheses that would be tested using PLS-SEM analysis (Hair, Hult, Ringle \& Sarstedt, 2017) as shown below:

H1:Transformational leadership has a positive influence on employees' perception of organizational change.

H2: Employees' perception of organizational change has a positive influence on affective commitment.

H3: Employees' perception of organizational change has a positive influence on normative commitment.

H4: Employees' perception of organizational change has a positive influence on continuance commitment.

H5: Employees' perception of organizational change has mediating effect on the relationship between transformational leadership and affective commitment. 
H6: Employees' perception of organizational change has mediating effect on the relationship between transformational leadership and normative commitment.

H7: Employees' perception of organizational change has mediating effect on the relationship between transformational leadership and continuance commitment.

\section{Methods}

\subsection{Sample and Data Collection}

255 survey questionnaires were distributed to all full time employees of XYZ Limited as at 1 February 2016. The breakdown of the population is $17 \%$ non-exempt employees, $37 \%$ administrative employees, $24 \%$ supervisory, and 22\% executive level. Questionnaires were sent out via emails and hard copies were distributed to those without email account. A total of 175 responses were collected with only 163 usable responses as 12 were incomplete or have more than one answer for some questions. This represents a $64 \%$ response rate $(\mathrm{N}=163)$. All completed survey feedbacks were entered into the SPSS software version 2.0 for processing (Table 1). Table 2 exhibits the demographic information.

Table 1: Survey Response Rate

\begin{tabular}{lccc}
\hline \multicolumn{1}{c}{ Item } & $\begin{array}{c}\text { Total Questionnaires } \\
\text { Distributed }\end{array}$ & $\begin{array}{c}\text { Total Usable Responses } \\
\text { Received }\end{array}$ & $\begin{array}{c}\text { Percentage } \\
(\%)\end{array}$ \\
\hline $\begin{array}{l}\text { Questionnaires distributed } \\
\text { online (email) } \\
\begin{array}{l}\text { Questionnaires distributed } \\
\text { personally (by hand) }\end{array}\end{array}$ & 207 & 134 & $64.7 \%$ \\
\hline Total usable questionnaire & 48 & 29 & $60.4 \%$ \\
\hline
\end{tabular}

Table 2: Profile of the respondents $(n=163)$

\begin{tabular}{|c|c|c|c|}
\hline Variable & Description & Number of Respondents & $\%$ \\
\hline 1. Age & $\begin{array}{l}\text { Below } 20 \text { years } \\
21-30 \text { years } \\
31-40 \text { years } \\
41-50 \text { years } \\
\text { Above } 50 \text { years }\end{array}$ & $\begin{array}{c}3 \\
38 \\
65 \\
40 \\
17\end{array}$ & $\begin{array}{c}1.8 \\
23.3 \\
39.9 \\
24.5 \\
10.4\end{array}$ \\
\hline 2. Gender & $\begin{array}{l}\text { Male } \\
\text { Female }\end{array}$ & $\begin{array}{l}74 \\
89\end{array}$ & $\begin{array}{l}45.4 \\
54.6\end{array}$ \\
\hline 3. Marital status & $\begin{array}{l}\text { Single } \\
\text { Married } \\
\text { Divorced / Widow }\end{array}$ & $\begin{array}{c}63 \\
93 \\
7\end{array}$ & $\begin{array}{c}38.7 \\
57.1 \\
4.3\end{array}$ \\
\hline 4. Job category & $\begin{array}{l}\text { Non-exempt } \\
\text { Exempt } \\
\text { Middle management } \\
\text { Senior management }\end{array}$ & $\begin{array}{l}29 \\
62 \\
38 \\
34\end{array}$ & $\begin{array}{l}17.8 \\
38.0 \\
23.3 \\
20.9\end{array}$ \\
\hline $\begin{array}{l}\text { 5. Number of years serving in the } \\
\text { organization }\end{array}$ & $\begin{array}{l}<1 \text { year } \\
\text { Between } 1-5 \text { years } \\
\text { Between } 5-10 \text { years } \\
>10 \text { years }\end{array}$ & $\begin{array}{l}26 \\
83 \\
26 \\
28\end{array}$ & $\begin{array}{l}16.0 \\
50.9 \\
16.0 \\
17.2\end{array}$ \\
\hline 6. Number of years serving in the industry & $\begin{array}{l}<1 \text { year } \\
\text { Between } 1-5 \text { years } \\
\text { Between } 5-10 \text { years } \\
>10 \text { years }\end{array}$ & $\begin{array}{l}16 \\
33 \\
38 \\
76 \\
\end{array}$ & $\begin{array}{c}9.8 \\
20.2 \\
23.3 \\
46.6 \\
\end{array}$ \\
\hline 7. Education level & $\begin{array}{l}\text { Secondary } \\
\text { Diploma } \\
\text { First Degree } \\
\text { Master Degree }\end{array}$ & $\begin{array}{c}18 \\
25 \\
104 \\
16\end{array}$ & $\begin{array}{c}11.0 \\
15.3 \\
63.8 \\
9.8\end{array}$ \\
\hline
\end{tabular}

\subsection{Measures}

A quantitative survey method (questionnaire) was used to collect data for this study. All items were measured using a 5-point Likert scale (1- Strongly Disagree to 5- Strongly Agree). Items for measuring 
the effectiveness of transformational leadership and its influence on employees' perception and their commitment to the organization were adopted from Bass and Avolio (1997). The reference source to design items to measure the employees' perception of the organizational change were adapted from Walston and Chadwick (2003). Items for the construction of affective, normative and continuance commitment to assess the level of commitment were adapted from Meyer, Stanley, Herscovitch and Topolnytsky (2002).

\subsection{Measurement Model}

In this study, VB-SEM Smart-PLS was applied to conduct the reliability and validity test. At the beginning of the process, the convergent validity was deployed to examine the question items, latent variable, average variance extract (AVE) and main loadings. Results have shown that all the Composite Reliability (CR) and Cronbach's Alpha (CA) are above 0.7 and 0.8 respectively, thereby fulfilling the requirement of Hair, Hult, Ringle and Sarstedt (2017). The Indicator Reliability and Loading for all items are greater than 0.7 and 0.8 respectively, except items AC3, CC3, EP3, NC1, NC2, TL1, and TL5 which were deleted due to main loading <0.7. The range of AVE for AC, NC, CC, EP, and TL are above 0.7. Given all the AVEs of constructs are above 0.5, there is a satisfactory degree of convergent validity suggested by Fornell and Larcker (1981). The results of the measurement model are presented in Table 3 and Figure 2.

The Heterotrait-Mnotrait (HTMT) confidence interval is a rigorous criterion relative to the traditional assessment proposed by Fornell and Larcker (1981). Recently, HTMT is highly recommended by Henseler, Ringle and Sarstedt (2015) with an argument that Fornell-Larcker criterion is not reliable in detecting lack of discriminant validity in common research situations, whereas HTMT has the capability to assess discriminant validity in variance-based SEM. According to Henseleret al. (2015), when testing the null hypothesis $\left(\mathrm{H}_{0}: \mathrm{HTMT} \geq 1\right)$ against the alternative hypothesis $\left(\mathrm{H}_{1}: \mathrm{HTMT}<1\right)$, if the confidence interval contains the value one (i.e., $\mathrm{H}_{0}$ holds) this indicates a lack of discriminant validity. The HTMT testing for this study showed HTMT confidence interval does not include one (1) indicated there is no problem of discriminant validity of the data (Table 3).

Table 3: Results of measurement model $(n=163)$

\begin{tabular}{|c|c|c|c|c|c|c|c|}
\hline \multirow{3}{*}{$\begin{array}{c}\text { Latent } \\
\text { Variable }\end{array}$} & \multirow{3}{*}{ Indicators } & \multicolumn{3}{|c|}{ Convergent Validity } & \multicolumn{2}{|c|}{$\begin{array}{c}\text { Internal Consistency } \\
\text { Reliability }\end{array}$} & \multirow{2}{*}{$\begin{array}{c}\begin{array}{c}\text { Discriminant } \\
\text { Validity }\end{array} \\
\text { HTMT }\end{array}$} \\
\hline & & Loadings & $\begin{array}{l}\text { Indicator } \\
\text { Reliability }\end{array}$ & AVE & $\begin{array}{l}\text { Composite } \\
\text { Reliability }\end{array}$ & $\begin{array}{c}\text { Cronbach's } \\
\text { Alpha }\end{array}$ & \\
\hline & & $>0.70$ & $>0.50$ & $>0.5$ & $0.60-0.90$ & $0.60-0.90$ & $\begin{array}{c}\text { HTMT } \\
\text { Confidence } \\
\text { interval does not } \\
\text { include } 1\end{array}$ \\
\hline$A C$ & $\begin{array}{l}A C 1 \\
A C 2\end{array}$ & $\begin{array}{l}0.921 \\
0.927\end{array}$ & $\begin{array}{l}0.848 \\
0.859\end{array}$ & 0.854 & 0.828 & 0.921 & YES \\
\hline$C C$ & $\begin{array}{l}C C 1 \\
C C 2 \\
E P 1\end{array}$ & $\begin{array}{l}0.904 \\
0.890 \\
0.901\end{array}$ & $\begin{array}{l}0.817 \\
0.792 \\
0.812\end{array}$ & 0.805 & 0.759 & 0.892 & YES \\
\hline$E P$ & $\begin{array}{l}E P 2 \\
E P 4\end{array}$ & $\begin{array}{l}0.896 \\
0.878\end{array}$ & $\begin{array}{l}0.803 \\
0.771\end{array}$ & 0.795 & 0.872 & 0.921 & YES \\
\hline$N C$ & $\begin{array}{l}N C 2 \\
T L 2 \\
T L 3\end{array}$ & $\begin{array}{l}1.000 \\
0.868 \\
0.832\end{array}$ & $\begin{array}{l}1.000 \\
0.753 \\
0.692\end{array}$ & 1 & 1 & 1 & YES \\
\hline$T L$ & $\begin{array}{l}T L 4 \\
T L 6 \\
T L 7 \\
T L 8\end{array}$ & $\begin{array}{l}0.845 \\
0.841 \\
0.844 \\
0.794\end{array}$ & $\begin{array}{l}0.714 \\
0.707 \\
0.712 \\
0.630\end{array}$ & 0.702 & 0.915 & 0.934 & YES \\
\hline
\end{tabular}

Note: AC3, CC3, EP3, NC1, NC2, TL1, TL5 were deleted due to main loading <0.7 


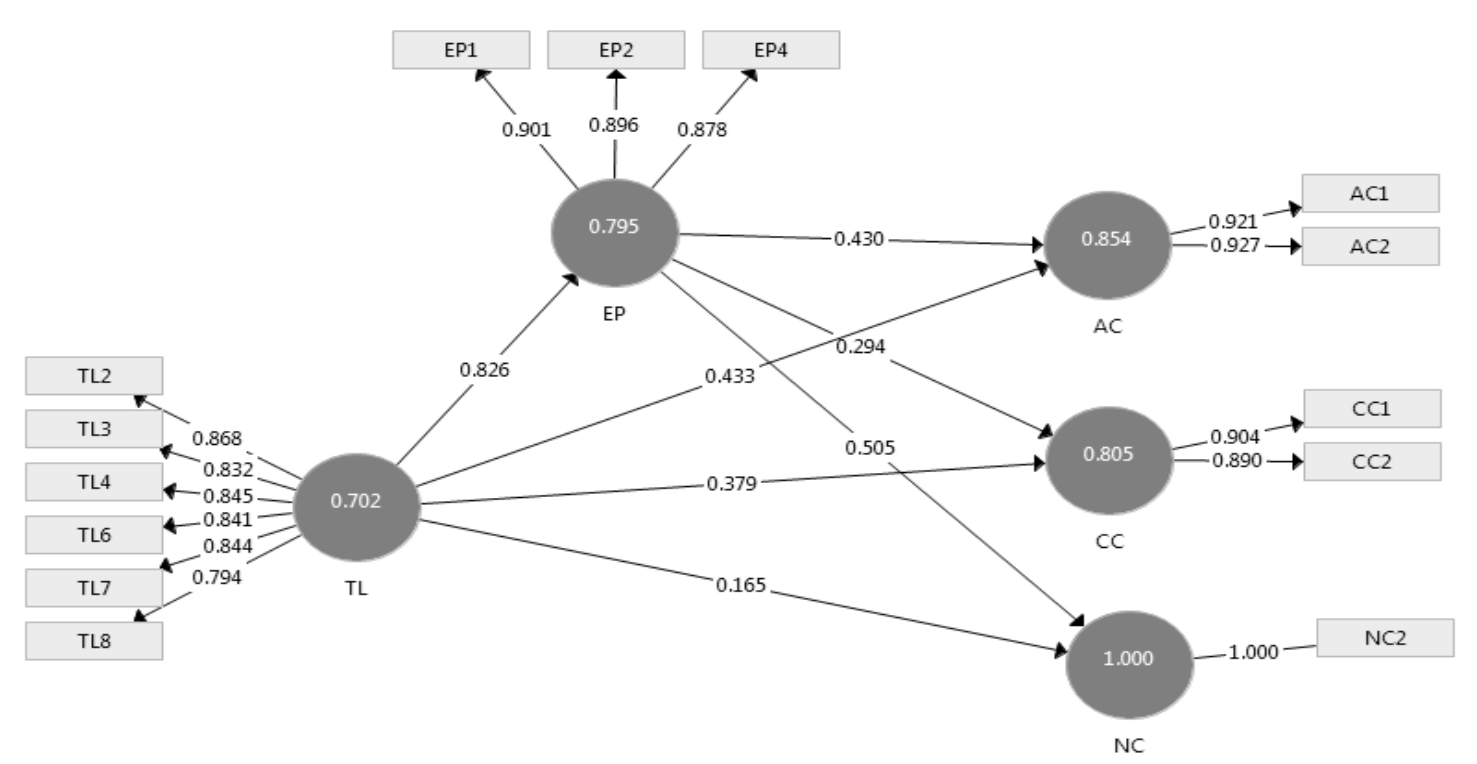

Figure 2: PLS-Path analysis of Beta value and R-square values $(\mathrm{n}=163)$

\subsection{Assessment of Structural Model}

Before proceeding to test structural model, $f^{2}$ effect sizes and $q^{2}$ effect sizes were deployed to test the invariance of the measurement items to examine if item measurement differed across the two groups (Hair, et al., 2017). According to the guidelines provided by Cohen (1988), $f^{2}$ values of $0.02,0.15$, and 0.35 represent small, medium, and large effects respectively. If the effect size value is less than 0.02 , it indicates that there is no effect. The results of $f^{2}$ values in Table 4 indicate all direct effects - Paths are at a satisfactory level, wherein the lowest is 0.02 (TL $\rightarrow \mathrm{NC}$ ) and the highest is 2.15 (TL $\rightarrow \mathrm{EP})$.

The $q^{2}$ effect size is similar to the $f^{2}$ effect size approach for assessing $\mathrm{R}^{2}$ value, wherein it assesses an exogenous construct's contribution to an endogenous latent variable's $Q^{2}$ value (Hair et al., 2017). The formula to compute the $q^{2}$ effect size is shown as follows:

$$
\mathrm{q}^{2}=\frac{\mathrm{Q}_{\text {included }}^{2}-Q_{\text {excluded }}^{2}}{1-Q_{\text {included }}^{2}}
$$

According to Hair et al. (2017), $\mathrm{q}^{2}$ values of $0.02,0.15$, and 0.35 represent small, medium, and large predictive relevance for a certain endogenous. The results of q2 values in Table 4 and Table 5 indicate this model has predictive relevant for all endogenous construct, wherein the lowest value of q2 is 0.06 and the highest is 1.00 .

The direct effects of the path coefficient of the structural model were measured by deploying bootstrapping analysis. The results showed TL has a positive relationship with EP $(\beta=0.826, \mathrm{p}<0.01)$. Also, EP has a positive relationship with $\mathrm{AC}(\beta=0.430, \mathrm{p}<0.01), \mathrm{NC}(\beta=0.505, \mathrm{p}<0.01)$, and $\mathrm{CC}(\beta=$ $0.294, \mathrm{p}<0.01$ ). Thus, all the direct effects, $\mathrm{H} 1, \mathrm{H} 2, \mathrm{H} 3$, and $\mathrm{H} 4$ were supported (Table 5).

Preacher and Hayes $(2004 ; 2008)$ bootstrapping method was used to test the indirect effects. The bootstrapping analysis revealed EP has mediating effect on the relationship between TL and AC ( $\beta=$ $0.355, \mathrm{p}<0.01)$, between TL andNC $(\beta=0.417, \mathrm{p}<0.01)$, and between TL and $\mathrm{CC}(\beta=0.243, \mathrm{p}<0.01)$ (Table 6). The results of the measurement model are presented in Figure 3. 
Table 4: Effect Size $q^{2}(n=163)$

\begin{tabular}{lrrrrrrrrr}
\hline & \multicolumn{3}{c}{$\mathbf{A C}$} & \multicolumn{3}{c}{$\mathbf{C C}$} & \multicolumn{3}{c}{ NC } \\
\hline & $\mathrm{Q}_{\text {Included }}^{2}$ & $\mathrm{Q}_{\text {Excluded }}^{2}$ & $q^{2}$ & $\mathrm{Q}_{\text {Included }}^{2}$ & $\mathrm{Q}^{2}$ Excluded & $q^{2}$ & $\mathrm{Q}_{\text {Included }}^{2}$ & $\mathrm{Q}_{\text {Excluded }}^{2}$ & $q^{2}$ \\
$\mathbf{E P}$ & 0.550 & 0.503 & 0.085 & 0.317 & 0.297 & 0.063 & 0.404 & 0.326 & 0.193 \\
$\mathbf{T L}$ & 0.550 & 0.502 & 0.087 & 0.317 & 0.282 & 0.110 & 0.404 & 0.398 & 0.020 \\
\hline
\end{tabular}

Table 5: Significance of direct effects- Path coefficients ( $\mathrm{n}=163)$

\begin{tabular}{cccccccc}
\hline Hypothesis & Relationship & Beta-value & SE & t-value & $\mathbf{f}^{2}$ & $\mathbf{q}^{2}$ & Decision \\
\hline H1 & TL $\rightarrow$ EP & 0.826 & 0.025 & 32.952 & 2.15 & 1.00 & Supported** \\
H2 & EP $\rightarrow$ AC & 0.430 & 0.072 & 5.965 & 0.18 & 0.09 & Supported** \\
H3 & EP $\rightarrow$ NC & 0.505 & 0.083 & 6.075 & 0.14 & 0.19 & Supported** \\
H4 & EP $\rightarrow$ CC & 0.294 & 0.098 & 3.004 & 0.05 & 0.06 & Supported** \\
\hline
\end{tabular}

Note: $* \mathrm{p}<0.05, * * \mathrm{p}<0.01, * * * \mathrm{p}<0.001, \mathrm{SE}=$ Standard Error

Table 6: Significance of indirect effects- Path coefficients ( $\mathrm{n}=163)$

\begin{tabular}{ccccccc}
\hline Hypothesis & Relationship & Beta-value & SE & t-value & $\begin{array}{c}\text { 95\% Confidence } \\
\text { Interval Effect }\end{array}$ & Decision \\
\hline H5 & TL $\rightarrow$ AC & 0.355 & 0.060 & 5.892 & {$[0.238,0.477]$} & Supported \\
H6 & TL $\rightarrow$ NC & 0.417 & 0.070 & 5.945 & {$[0.281,0.555]$} & Supported \\
H7 & TL $\rightarrow$ CC & 0.243 & 0.082 & 2.977 & {$[0.091,0.413]$} & Supported \\
\hline
\end{tabular}

Note: $* \mathrm{p}<0.05, * * \mathrm{p}<0.01, * * * \mathrm{p}<0.001, \mathrm{SE}=$ Standard Error

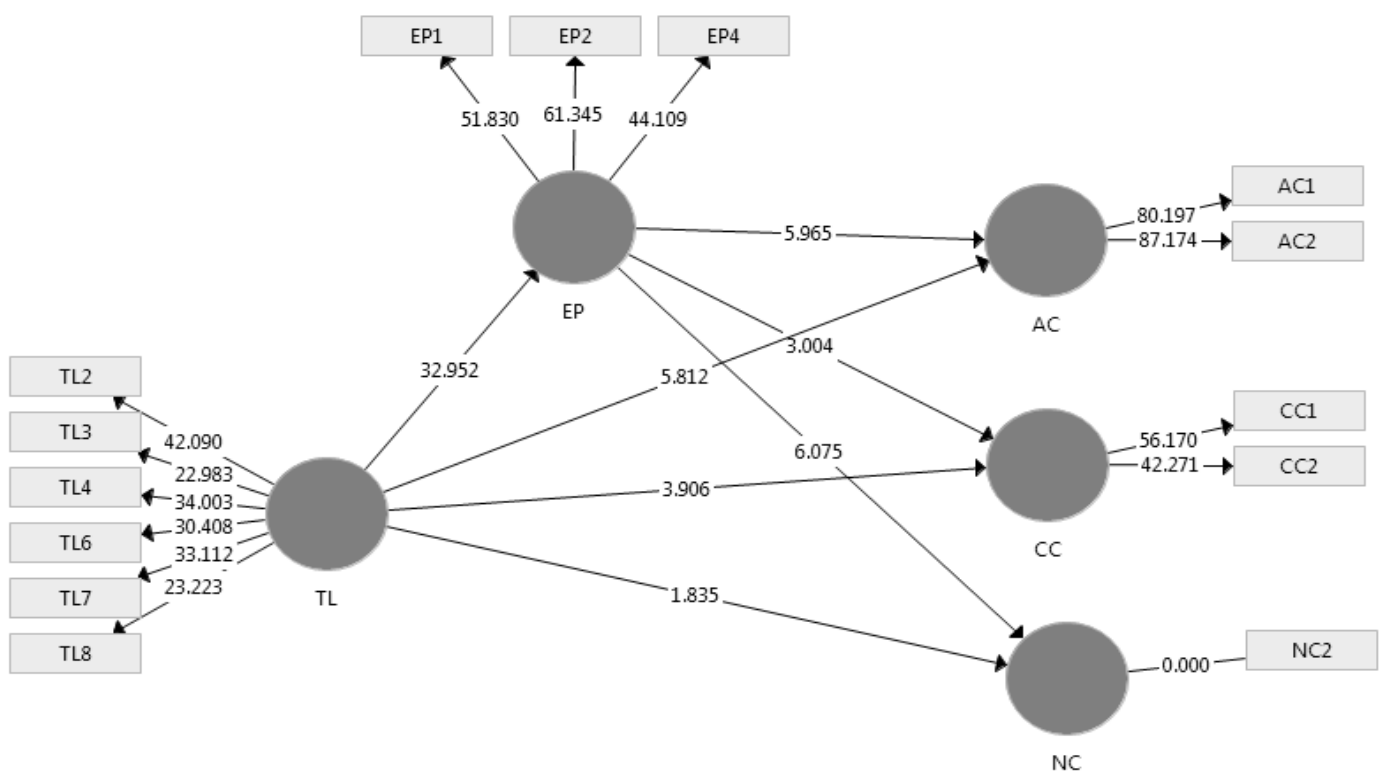

Figure 3: PLS-Path analysis of $\mathrm{t}-\mathrm{values}(\mathrm{n}=163)$

\section{Discussions and Recommendations}

This study suggests that transformational leadership (TL) has a positive influence on employees' perception of organizational change (EP); and EP has a positive influence on their affective commitment (AC), normative commitment (NC), and continuance commitment (CC). The recognition of EP as a mediator in the relationship between TL and employees' commitment (AC, NC and CC) helps the management team of XYZ Limited to develop appropriate strategies to improve transformational leadership behaviors within the organization. Improved TL will then influence EP positively, and thus 
enhance their commitment towards the organization.

In order to improve TL, proper trainings should be made available to the management team of XYZ Limited to enable them to learn the ways to motivate, coach, support and guide the employees through changes, and to communicate changes effectively. Leading and gaining employees' commitment is one of the most challenging tasks for the leaders. Therefore, the management team should understand the causes of employees' resistance to change and find ways to overcome such resistance. Many times, employees' resistance to change is due to their uncertainty or fear towards the change. Managers should communicate effectively the purpose, vision and benefits of the changes to the employees. When employees understand the change initiatives, plus the support and coaching given by the transformational leaders to guide them through the change, it will lead to a reduction in resistance.

In addition, it is also important for the managers themselves to be role models by demonstrating enthusiasm, optimism and commitment to the change as well as the organization. This will build confidence and trust among the employees. When employees trust their leaders and see the value in the change, it will reduce their resistance to change, and at the same time, increase their support and commitment.

Besides focusing on enhancing TL, management team should also pay attention to the capabilities of the employees to perform their tasks during the change. If employees were found inept in performing their new tasks, trainings and skills development programmes should be introduced to the employees. When the employees are better equipped and have the competency to deal with the unfamiliar situations caused by the changes, their fear of uncertainty, job instability and inability to cope with the changes will reduce, and their confidence level increases. This will give the employees a sense of control and increase their acceptance of the changes leading to higher employees' affective commitment towards the changes.

\section{Practical and Theoretical Implication of the Study}

This study has shown that the EP fully mediates the relationship between TL and employees' commitment. TL has a direct effect on EP, and an indirect effect on AC, NC and CC.

The direct and indirect influences of TL on EP and employees' commitment were analyzed with the hope that the findings from this study will enable the organizations to develop appropriate strategies to positively influence the employees' commitment to support the changes and lead to successful organizational change initiatives.

Future research can focus on other organizational context besides the telecommunication industry to determine if results may differ. Similar study can be extended to other types of leadership to investigate if it would bring similar effect.

\section{Conclusion}

This study aims to provide insights on how transformational leadership is able to influence the employees' commitment to the organization, and the mediating role of employees' perception of the changes in this relationship. Results shown that (1) transformational leadership has a positive influence on employees' perception of organizational change; (2) employees' perceptional of organizational change has a positive influence on the employees' affective, normative and continuance commitment; and (3) employees' perception of organizational change has mediating effect on the relationship between transformational leadership and organizational commitment (AC, NC and CC).

\section{References}

Alas, R. \&Vadi, M. (2006). The employees' attitudes and their connections with the organisational culture in the process of change in the Estonian organisations.Baltic Journal of Management, 1(1), 49-66.

Allen, N.J. \& Meyer, J.P. (1990). The measurement and antecedents of affective, continuance and 
normative commitment to the organization.Journal of Occupational Psychology, 63, 1-18.

Avolio, B.J., Zhu,W., Koh, W. \& Bhatia, P. (2004). Transformational leadership and organizational commitment: Mediating role of psychological empowerment and mediating role of structural distance. Journal of Organizational Behavior, 25, 951-968.

Barker, III, V. \&Duhaime, I.M. (1997). Strategic change in the turnaround process: Theory and empirical evidence. Strategic Management Journal, 18(1), 13-38.

Bass, B.M. (1990). From transactional to transformational leadership: Learning to share the vision. Organizational Dynamics, 18(3), 19-31.

Bass, B.M., \&Avolio, B.J. (1990).The implications of transactional and transformational leadership for individual, team, and organizational development.Research in Organizational Change and Development, 4, 231-272.

Bass, B.M. \& Avolio, B.J. (1997). Full Range Leadership Development: Manual for the Multifactor Leadership Questionnaire. Palo Alto, USA: Mind Garden Inc.

Bass, B.M., Avolio, B.J., Jung, D.I. \&Berson, Y. (2003).Predicting unit performance by assessing transformational and transactional leadership, Journal of Applied Psychology, 88(2), 207-218.

Bass, B.M. \&Riggio, E.G. (2006).Transformational Leadership. Mahwah, NJ: Lawrence Erlbaum Associates.

Becker, H.S. (1960). Concept of commitment.The American Journal of Sociology, 66(1), 32-40.

Beer, M. \&Nohria, N. (2000).Cracking the code of change.Harvard Business Review, 782, 133-141.

Bem, D. (1972). Self-perception theory. In: L. Berkowitz (Ed.). Advances in Experimental Social Psychology, 6, 1-62. New York: Academic Press.

Bernerth, J. (2004). Expanding our understanding of the change message.Human Resource Development Review, 3(1), 36-52.

Bibeault, D. B. (1982).Corporate Turnaround: How Managers Turn Losers into Winners. New York: McGraw Hill.

Boselie, P. \&Koene, B. (2010). Private equity and human resource management: Barbarians at the gate! HR's wake-up call?.Human Relations, 63(9), 1297-1319.

Burns, J.M. (1978). Leadership. New York: Harper \& Row.

Chan, S.C.H.\&Mak, M.W. (2014).The impact of servant leadership and subordinates' organizational tenure on trust in leader and attitudes.Personnel Review, 43(2), 272-287.

Cohen, J. (1988). Statistical Power Analysis for the Behavioral Sciences. Mahwah, NJ: Lawrence Erlbaum.

Cohen, S.G., Chang, L. \& Ledford, G.E. (1997).A hierarchical construct of self-management leadership and its relationship to quality of work life and perceived work group effectiveness.Personnel Psychology, 50, 275-308.

Conner, D. R. (1993).Managing at the Speed of Change: How Resilient Managers Succeed and Prosper Where Others Fail. New York: Villard Books.

Cossin, D. \& Caballero, J. (2013).Transformational Leadership Background Literature Review.IMD Global Board Center. from https://www.imd.org/uupload/IMD.WebSite/BoardCenter/Web/213/Literature\%20Review_Transf ormational\%20Leadership.pdf

Dervitsiotis, K.N. (1998). The challenge of managing organizational change: Exploring the relationship of re-engineering, developing learning organizations and total quality management. Total Quality Management, 9(1), 109-122.

DiVitto, B. \& McArthur, L. Z. (1978). Developmental differences in the use of distinctiveness, consensus, and consistency information for making causal attributions . Developmental Psychology, 14, 474482.

Dodd, N.G. \&Ganster, D.C. (1996). The interactive effects of variety, autonomy and feedback on attitudes and performance.Journal of Organizational Behavior, 17(4), 329-38.

Eby, L. T., Freeman, D. M., Rush, M. C. \& Lance, C. E. (1999). Motivational bases of affective commitment: A partial test of an integrative theoretical model. Journal of Occupational and 
Organizational Psychology, 72, 463-483.

Eisenberger, R., Huntington, R., Hutchison, S. \& Sowa, D. (1986).Perceived organizational support.Journal of Applied Psychology, 71, 500-507.

Ellis, A. P. J., Ilgen, D. R., \& Hollenbeck, J. R. (2006). The effects of team leader race on performance evaluations. Small Group Research, 37, 295-332.

Ford, J.D., Ford, L.W. \&D'Amelio, A. (2008). Resistance to change: The rest of the story. Academy of Management Review, 33(2), 362-77.

Fornell, C. \& Larcker, D. F. (1981). Evaluating structural equation models with unobservable variables and measurement error. Journal of Marketing Research, 18, 39-50.

Gillespie, N. A. \& Mann, L. (2004). Transformational leadership and shared values: The building blocks of trust. Journal of Managerial Psychology. 19, 588-607.

Goldstein, J. (1988). A far-from equilibrium systems approach to resistance to change.Organizational Dynamics, 17, 16-26.

Greiner, L.E. (1992). Resistance to change during restructuring.Journal of Management Inquiry, 1, 61-65.

Groves, K.S. (2005). Linking leader skills, follower attitudes and contextual variables via an integration of charismatic leadership.Journal of Management, 31, 255-277.

Hackett, R. D. \&Bycio, P. A. (1994).Further assessment of Meyer and Allen's (1991) Three-Component Model of organizational commitment.Journal of Applied Psychology, 79(1), 15-23.

Hair, Jr.J.F., Hult, G.T.M., Ringle, C.M. \& Sarstedt, M. (2017). A Primer on Partial Least Squares Structural Equation Modeling (PLS-SEM). 2nd ed. London, U.K.: SAGA Publications, Inc.

Hambrick, D.C. \&Schecter, S.M. (1983).Turnaround strategies for mature industrial-product business units.Academy of Management Journal, 26(2), 231-248.

Hannan, M. T. \& Freeman, J. (1988).Structural inertia and organizational change.In K. Cameron, R. Sutton \&Whetten, D. (Eds.).Readings in organizational change, 75-94. Cambridge, MA: Ballinger.

Henseler, J., Ringle, C. M. \& Sarstedt, M. (2015). A new criterion for assessing discriminant validity in variance-based structural equation modeling . Journal of the Academy of Marketing Science, 43(1), 115-135.

Herscovitch, L. \& Meyer, J. P. (2002). Commitment to organisational change: Extension of a ThreeComponent Model. Journal of Applied Psychology, 87, 474-487.

Hofer, C. W. (1980). Turnaround strategies.Journal of Business Strategy, 1, 19-31.

Johnson, M.W., Parasuraman, A., Futrell, C.M. \& Black, W.C. (1990).A longitudinal assessment of the impact of selected organizational influences on salespeople's organizational commitment during early employment.Journal of Marketing Research, 27(3), 333-344.

Korkmaz, M. (2007).The effects of leadership styles on organizational health.Educational Research Quarterly, 30(3), 2-54.

Kotter, J. P. \& Cohen, D. S. (2002).The Heart of Change: Real-life Stories of How People Change Their Organizations. Boston, MA: Harvard Business School Press.

Lamm, E. \& Gordon, J. R. (2010).Empowerment, predisposition to resist change and support for organizational change.Journal of Leadership \& Organizational Studies, 17(4), 426-437.

Li, C. \& Hung, C. (2009).The influence of transformational leadership on workplace relationships and job performance.Social Behavior and Personality, 37(8), 1129-1142.

Lord, R.G. \&Emrich, C.G. (2001). Thinking outside the box by looking into the box: Extending the cognitive revolution in leadership research. The Leadership Quarterly, 11(4), 551-579.

Machin, M.A., Fogarty, G.J. \& Bannon, S.F. (2009).Predicting employees' commitment to and support for organisational change. The Australian and New Zealand Journal of Organisational Psychology, 2(1), 10-18.

Martin, A.J., Jones, E.S. \& Callan, V.J. (2006).Status differences in employee adjustment during organizational change.Journal of Managerial Psychology, 21(2), 145-162.

Martin, M.M. (1998). Trust leadership. Journal of Leadership Studies, 5(13), 41-48.

Mert S. I, Keskin, N \& Bas, T. (2010). Leadership style and organizational commitment: Test of a theory in Turkish banking sector. Journal of Academic Research in Economics, 2, 1-20.

Meyer, J. \& Allen, N. (1997).Commitment in the Workplace: Theory, Research, and Application. New 
York: Sage Publications.

Meyer, J.P., \& Allen, N.J. (1991).A three-component conceptualization of organizational commitment.Human Resource Management Review, 1, 61-89.

Meyer, J. P., Gagné, M. and Parfyonova, N.M. (2010).Toward an evidence-based model of engagement: What we can learn from motivation and commitment research. In S. L. Albrecht (Ed.), The Handbook of Employee Engagement: Perspectives, issues, research and practice, 62-73.

Meyer, J. P., Stanley, D. J., Herscovitch, L. \&Topolnytsky, L. (2002). Affective, continuance and normative commitment to the organization: A meta-analysis of antecedents, correlates, and consequences, Journal of Vocational Behavior, 61, 20-52.

Miles, J.A. (2012). Management and Organization Theory. San Francisco, CA: Jossey-Bass.

Noble, C.H. \&Mokwa, M.P. (1999).Implementing marketing strategies: Developing and testing a managerial theory.Journal of Marketing, 63(4), 57-73.

Parish, J.T., Cadwallader, S. \& Busch, P. (2008).Want to, need to, ought to: Employee commitment to organizational change. Journal of Organizational Change Management, 21(1), 32-52.

Podsakoff P. M., MacKenzie S. B. \&Bommer W. H. (1996). Transformational leader behaviors and substitutes for leadership as determinants of employee satisfaction, commitment, trust and organizational citizenship behaviors.Journal of Management, 22(2), 259-298.

Porter, L., Steers, R., Mowday, R. \&Boulian, P. (1974). Organizational commitment, job satisfaction, and turnover among psychiatric technicians.Journal of Applied Psychology, 59(5), 603-609.

Preacher, K.J. \& Hayes, A.F. (2004). SPSS and SAS procedures for estimating indirect. Behavior Research Methods, Instruments, \& Computers, 36(4), 717-731.

Preacher, K.J. \& Hayes, A.F. (2008). Asymptotic and resampling strategies for assessing and comparing indirect effects in multiple mediator models. Behavior Research Methods, 40(3), 879-891.

Spreitzer, G.M., Perttula, K.H. \& Xin, K. (2005).Traditionality matters: An examination of the effectiveness of transformational leadership in the United States and Taiwan. Journal of Organizational Behavior, 26, 205-227.

Tseng, H.C. \& Kang, L.M. (2008). How does regulatory focus affect uncertainty towards organizational change? Leadership \& Organization Development Journal, 29(8), 713- 731.

Van Dijk, R. \& Van Dick, R. (2009). Navigating organizational change: Change leaders, employee resistance and work-based identities. Journal of Change Management, 9(2), 143-163.

Vithessonthi, C. (2007). Perceptions affecting employee reactions to change: Evidence from privatization in Thailand. Journal of American Academy of Business, 12(1), 248-255.

Walston, S.L. \& Chadwick, C. (2003). Perceptions and misperceptions of major organisational changes in hospitals: Do change efforts fail because of inconsistent organisational perceptions of restructuring and reengineering? International Journal of Public Administration, 26(14), 1581-1605.

Walumbwa, F. O., Wang, P., Lawler, J. J. \& Shi, K. (2004).The role of collective efficacy in the relations between transformational leadership and work outcomes.Journal of Occupational and Organizational Psychology, 77, 515-530.

Weick, K. E. (1999). Theory construction as a disciplined reflexivity: Tradeoffs in the 1990s. Academy of Management Review, 24, 797-806.

Weiner, Y. (1982). Commitment in organizations: a normative view. Academy of Management Review. 7 , 418-428.

Yukl, G. (2002). Leadership in Organizations. 5th ed. Upper Saddle River: Prentice-Hall. 
